\title{
RESISTÊNCIA DEMOCRÁTICA VERSUS GRAVES VIOLAÇÕES DOS DIREITOS HUMANOS DURANTE A DITADURA MILITAR NO PARANÁ : A ATUAÇÃO DOS ADVOGADOS NA DEFESA DE PRESOS POLÍTICOS
}

\author{
Democratic resistance vs. serious human rights violations \\ during the military dictatorship in Paraná: the role of \\ lawyers in the defense of political prisoners
}

\author{
Leandro Brunelo* \\ Angelo Priori**
}

\begin{abstract}
RESUMO
Durante a ditadura militar, o Estado empregou dispositivos legais para legitimar as suas ações jurídicas e punitivas contra a oposição política, em especial, os militantes do Partido Comunista Brasileiro (PCB) no Paraná. Esses militantes foram presos e indiciados pelo Inquérito Policial-Militar 745 (IPM 745), que apurou o envolvimento dos comunistas na suposta organização do partido no Estado, em 1975. Ao problematizarmos o IPM em tela, destacamos as vozes do Estado, enquanto instituição política que controla e formula as leis, e dos advogados de defesa das pessoas presas que denunciaram as violações dos direitos humanos. Tanto os advogados como o Estado eram dois agentes sociais e políticos presentes em um campo específico, o jurídico, no qual ocorria a disputa de forças entre narrativas de defesa e de acusação. Sendo assim, dois agentes díspares na escala do poder travaram uma batalha legal e jurídica, e os advogados, por sua vez,
\end{abstract}

\footnotetext{
* Doutor em História. Professor do Departamento de História e do Programa de Mestrado Profissional em Ensino de História (ProfHistória) da Universidade Estadual de Maringá/PR. E-mail: leandrobrunelo@ig.com.br

** Doutor em História. Professor do Programa de Pós-Graduação em História da Universidade Estadual de Maringá/PR. E-mail: angelopriori@uem.br
} 
valiam-se do mesmo substrato burocrático-legal formulado pelo Estado para tornar menos rígidos os limites da lei e do campo jurídico.

Palavras-chave: inquérito policial-militar; advogados; ditadura militar.

\begin{abstract}
During the military dictatorship, the State used legal devices to legitimize its legal and punitive actions against the political opposition, in particular the militants of the Brazilian Communist Party (PCB) in Paraná who were arrested and indicted by Military-Police Inquiry 745, which verified the involvement of the Communists in the supposed organization of the party in the State in 1975 . When we questioned the IPM on the screen, we try to evoke the voices of the State, as a political institution that controls and formulates laws, and of advocates for the defense of people prisoners who the violations of human rights. Both the lawyers and the state were two social and political agents present in a specific field, the legal one, in which there was a dispute of forces between defense's and accusation's narratives. Thus, two disparate agents on the scale of power engaged in a legal and legal battle, and lawyers, in turn, used the same bureaucratic-legal substratum formulated by the state to make the limits of the law and the legal field less rigid.
\end{abstract}

Keywords: Military-Police Investigation 745; lawyers; military dictatorship.

\title{
Introdução
}

O Direito possui como uma de suas definições o ordenamento normativo e coativo da sociedade, uma vez que reúne um conjunto de normas de conduta e de organização social que regulamentam as relações de convivência e de sobrevivência dos grupos sociais. Esse conjunto de normas, por seu turno, possui uma dinâmica que visa assegurar a manutenção e a preservação do corpo social, evitando a sua destruição e possibilitando que os conflitos entre as pessoas sejam equacionados, o que assegura, então, a ordem e a paz sociais.

Para Norberto Bobbio, o Direito pode recorrer à força física para se fazer respeitar os princípios normativos de conduta em sociedade e, quando o faz, a sua ligação com a política se estreita a ponto de "considerar o Direito como principal instrumento através do qual as forças políticas, que 
têm nas mãos o poder dominante em uma determinada sociedade" (BOBBIO et. al., 2000, p. 349), exercendo, assim, o domínio político e social.

A aproximação entre Direito e política ocorreu com o nascimento do Estado Moderno e, a partir desse fenômeno, o uso do poder passou a ser usufruto do Estado, sendo legitimado e limitado pelas prerrogativas jurídicas. Ainda conforme Bobbio, o que houve a partir desse evento foi a estatização do Direito e a juridificação do Estado. O Direito, do ponto de vista estatal, seria um conjunto de regras impostas ou não pelo grupo que detém o poder soberano, e o Estado, de acordo com o ordenamento jurídico, representaria o Estado de Direito, um sistema institucional crivado por uma situação jurídica inerente a uma série de dispositivos constitucionais, de leis, de normas jurídicas e de regulamentos.

A convergência das estruturas jurídicas e políticas, personificadas pelo Estado, fez com que o Direito se reduzisse a um tipo de ordenamento jurídico que se identificasse com a ordenação coativa estatal, e o Estado, por sua vez, a um Estado jurídico que manipularia a produção jurídica, logo, "as fontes de produção do Direito", bem como dominaria os aparelhos de coação sociopolítica (BOBBIO et. al., 2000, p. 349).

$\mathrm{Na}$ relação estabelecida entre Estado e Direito ${ }^{1}$, os mecanismos jurídicos contribuiriam para que o uso do poder pelo Estado não extrapolasse seus limites, sendo, então, promotor da justiça e da igualdade social. Entretanto, esses mesmos dispositivos da área jurídica que, em princípio, salvaguardariam a justiça e o seu exercício, também poderiam legitimar uma ordem política que não teria sintonia com os valores democráticos e, muito menos, com as prerrogativas do Estado de Direito. Foi o que presenciamos a partir de 1964, quando os militares apoiados pelos setores conservadores da sociedade brasileira tomaram o poder (GALLO, 2014).

1 Apresentamos a ideia de que Direito e justiça são conceitos que se entretecem de tal maneira que podem ser considerados portadores de um mesmo sentido. Entretanto, é preciso salientar, embora essa ressalva não se atrite com a noção elencada em nosso texto, que esses conceitos nem sempre estão entrelaçados, uma vez que o Direito pode não ser justo a todo momento, assim como o que é justo pode não ser considerado de tal forma pelo Direito. Sobre essa discussão, chamamos a atenção para a Teoria Pura do Direito promovida pelo jurista Hans Kelsen e que se refere a uma teoria do Direito positivo, que se preocupa em compreender o que é e como é o Direito e não a maneira como deve ser feito, o que seria considerado como política do Direito. Isto não é o desejo da teoria pura, pois trata-se de uma ciência jurídica que objetiva conhecer o Direito excluindo tudo o que não pertença estritamente ao seu objeto (KELSEN, 1999). 
Logo após o golpe civil-militar desfechado em março de 1964, centenas de Inquéritos Policial-Militares (IPMs) foram instaurados, cujo objetivo investigativo e, também, persecutório desses mecanismos jurídicos alcançou, no primeiro ano de ditadura militar, "50 mil oponentes, ou seja, 10 mil réus e 40 mil testemunhas [que] teriam sido afetados por essa caça às bruxas da qual teriam participado mais de 3 mil oficiais" (CHIRIO, 2012, p. 67).

Este artigo abordará, especialmente, o IPM $745^{2}$ instaurado no Paraná em 1975, quando a operação policial-militar chamada Marumbi ${ }^{3}$ foi organizada e executada para prender militantes do Partido Comunista Brasileiro (PCB) acusados de rearticularem o partido no Paraná, o que feria o artigo no 43 da Lei de Segurança Nacional (LSN) ${ }^{4}$, que consistia em reorganizar ou tentar colocar em funcionamento agremiação política que estivesse proscrita por força de lei.

O IPM em tela teve o objetivo de apurar o envolvimento das pessoas presas, 65 no total, acusadas de estruturar o PCB no Estado, e nos possibilitou compreender que dispositivos jurídicos dessa natureza eram permeados por ações criminosas do próprio Estado, uma vez que as pessoas indiciadas, antes presas e situadas nas dependências dos organismos de segurança, sofreram ameaças psicológicas e torturas físicas, o que demonstrou o uso arbitrário do poder e o desrespeito aos direitos humanos.

Os casos de violência foram, ao longo do IPM, sobretudo em sua fase judicial, ressaltados pelos advogados de defesa dos presos políticos, que sublinharam o autoritarismo e a truculência estatal, a fim de tentar reverter o discurso de acusação que era dirigido aos seus clientes. Nesse

2 O IPM 745 foi coligido pelo projeto Brasil: Nunca Mais (BNM), quando no trajeto jurídico atingiu a esfera do Superior Tribunal Militar (STM) e passou a ser renomeado de BNM 551. Em nosso artigo, trataremos-o como apenas IPM 745, obtido junto ao Arquivo Edgar Leuenroth (AEL), na Unicamp e que atualmente se encontra disponível na internet, no endereço eletrônico do projeto BNM: <http://bnmdigital.mpf.mp.br/sumarios/600/551.html>. Acesso em: 10 jul. 2019.

3 Sobre a Operação Marumbi, ver: Brunelo (2009; 2019).

4 No Brasil, tivemos diversas Leis de Segurança Nacional (LSN). A primeira foi instituída em abril de 1935, quase como uma resposta à fundação da Aliança Libertadora Nacional (ALN), movimento que lutava contra o regime de exceção varguista. Esta lei foi modificada em 1938, logo após o putsch integralista (movimento armado deflagrado contra o governo federal pela Ação Integralista Brasileira (AIB). Depois, em janeiro de 1953, no chamado interregno democrático, tivemos a publicação de uma nova Lei de Segurança Nacional. E por fim, durante o período da ditadura militar tivemos a publicação de 4 leis: uma em março de 1967, outra em setembro de 1969, a terceira em dezembro de 1978, com o fim do Ato Institucional No. 5 (AI-5), e a quarta, publicada em dezembro de 1983, que vigora até os dias atuais. Para isto ver: Reznik (2004), Priori (2016) e Ipólito (2016). 
sentido, o trabalho realizado por esses juristas, durante a ditadura militar e problematizados neste artigo, permitem-nos compreender que o aparato jurídico-legal do Estado era obliterado por ações incompatíveis com o seu verniz de legitimidade e, também, tornam visíveis a vulnerabilidade dos segmentos sociais, como os militantes do PCB, atingidos pelas práticas repressivas estatais e envolvidos por um arranjo burocrático legal, porém autoritário, do qual, inclusive, os advogados se apropriaram para levar adiante o seu trabalho de defesa dos presos políticos.

\section{Embate legal entre o Estado e os advogados do IPM 745}

Dois fenômenos sociais ajudam a entender a manipulação dos instrumentais jurídico-legais pelo Estado, a fim de servir a uma determinada ideologia, são eles: o apartheid sul-africano e o Nazismo. Nos dois casos houve a violação dos direitos individuais, tanto da população negra - majoritária na África do Sul, mas segregada dos direitos sociais básicos pela elite branca - quanto dos judeus, dos ciganos e dos homossexuais, que foram enquadrados por uma política eugenista nazista, que provocou muitas perseguições e mortes. Para Gallo, a legalidade dos atos de segregação e de perseguição eram adequados do ponto de vista formal, mas indiscutível era a sua injustiça "objetivada com a aplicação das regras vigentes" (GALLO, 2014, p. 34).

No Brasil, guardadas as devidas proporções, vivemos uma situação análoga durante o regime militar, do ponto de vista jurídico, pois a legitimidade das ações desencadeadas pelo governo autoritário estava calcada na lei, portanto, sustentada por elementos formais e legalistas. Contudo, a concretude dos decretos, dos decretos-leis, dos projetos de lei, das emendas constitucionais e de uma nova Constituição produzidas ao longo de duas décadas de autoritarismo dava ao Estado uma grande quantidade de poder, mas que era carente de equilíbrio e de justiça, sobretudo com as pessoas ideologicamente contrárias ao governo.

A legislação autoritária, cuja formulação foi orientada pelos aparatos ideológicos da Doutrina de Segurança Nacional (DSN), permitiu 
BRUNELO, L.; PRIORI, A. Resistência democrática versus graves violações dos direitos...

ao Estado, representado pelo Judiciário, julgar os elementos sociais considerados perigosos, uma vez que afrontavam o regime com as suas maneiras de pensar e de agir. Esses inimigos internos que cometiam crimes contra a segurança nacional eram julgados por Juízes Militares e submetidos a um Procurador da Justiça Militar, dentre outras dinâmicas jurídico-legais.

Conforme o livro relatório Brasil: nunca mais, a DSN, formulada pela Escola Superior de Guerra (ESG), forneceu outra percepção em relação ao princípio de segurança nacional, cuja LSN podia ser "aquela que concentra e condensa todos os critérios e conceitos enfeixados pela Doutrina de Segurança Nacional" (ARQUIDIOCESE DE SÃO PAULO, 1985, p. 75), que se ramificaram no campo da legislação e das instituições de Estado.

Durante 21 anos de ditadura militar, como destacou Gallo:

[...] a Ditadura Civil-Militar no Brasil deixaria de herança, como saldo da repressão (além dos resquícios psicológicosociais estabelecidos pela DSN), o número de aproximadamente cinquenta mil pessoas presas somente nos primeiros meses que se seguiram ao golpe, de pelo menos 426 mortos e desaparecidos políticos (incluídos nesse cálculo trinta casos ocorridos no exterior), uma quantidade até hoje desconhecida de mortos em manifestações públicas, 7.367 pessoas indiciadas e 10.034 atingidas pelos inquéritos realizados em 707 processos que tramitaram na Justiça Militar, enquadradas nos crimes contra a Lei de Segurança Nacional, quatro cidadãos condenados à pena de morte (não consumada), 130 banidos, 4.862 indivíduos cassados, 6.592 militares atingidos, milhares de exilados e centenas de camponeses assassinados (GALLO, 2014, p. 39).

Esse saldo negativo se consubstanciou, porque havia uma estrutura repressiva atuante, bem como um sistema legal e jurídico à disposição do Estado, uma vez que, durante esses dois decênios, "foram produzidas 01 Constituição, 17 Atos Institucionais, 105 Atos Complementares e 42 Emendas Constitucionais, incluindo a Emenda no 01/69 que de tão extensa ficou conhecida como a 'Constituição de 1969"” (SILVA, 2009, p. 21). 
Percebemos, então, que o Direito foi instrumentalizado pelo Estado, embora devamos salientar que esse procedimento não foi total e absoluto, pois as leis criadas, muitas vezes, permitiram manobras jurídicas que não se coadunavam com os princípios da segurança nacional exaltados pelo regime político. Essas brechas da lei eram exploradas pelos advogados de defesa dos presos políticos, pois eles almejavam obter alguns benefícios para os seus clientes, em virtude da existência dessas fendas no aparato legislativo e, concomitantemente, flexibilizar e expandir as delimitações das interpretações legais no âmbito dos tribunais.

O trabalho que os advogados realizaram no período da ditadura militar não era fácil, uma vez que, para defenderem os presos, entravam em atrito com o Estado e salientavam as irregularidades na condução dos processos judiciais, destacando arbitrariedades cometidas pelos órgãos de segurança e o desrespeito ao cumprimento das prerrogativas legais.

Atualmente, os advogados são resguardados pela Constituição Federal de 1988, visto que os seus direitos e garantias são previstos na Carta constitucional, conforme consta no Capítulo IV: Das funções essenciais à Justiça, Seção III: Da advocacia, artigo 134: "O advogado é indispensável à administração da justiça, sendo inviolável por seus atos e manifestações no exercício da profissão, nos limites da lei” (BRASIL, 1988).

A figura do causídico passou a ser vista como essencial para a gerência da Justiça no Brasil. O cenário de hoje é contrastante com a situação deparada pelos advogados na fase política, que Heleno Cláudio Fragoso (1984) chamou de "os anos difíceis". Fragoso, reconhecido advogado que atuou sistematicamente contra os abusos da ditadura militar, sublinhou o adjetivo "difíceis" para se referir àqueles anos, pois o Brasil ganhava visibilidade internacional devido às ondas de torturas que assolavam o país e que eram recorrentes nos cárceres.

Lidar com a máquina de repressão estatal e com um esquema legalista, muitas vezes, transgredido pela própria Justiça Militar era um jogo perigoso, que se complicava ainda mais quando os agentes da repressão tinham convicção do que faziam, ou seja, de lutar contra o comunismo, mesmo que isso implicasse na disseminação do terror junto aos opositores políticos, suas famílias e, também, advogados de defesa. 
Internacionalmente, o país era destaque em documentos de organismos internacionais que acusavam a prática de torturas ${ }^{5}$ em nosso território. "A Comissão Internacional dos Direitos Humanos pronunciou-se mais de uma vez, condenando o governo brasileiro pela tortura infligida a presos políticos. O Papa Paulo VI também se referiu abertamente à matéria" (FRAGOSO, 1984, p. 146).

Portanto, no exterior, as organizações políticas e as figuras religiosas davam destaque para os problemas vividos internamente e pelas transgressões impostas aos direitos humanos. Cabia aos advogados, quando procurados pelos familiares dos presos políticos, tentar mitigar essa onda de infração e de violação dos direitos inerentes à pessoa humana.

Quando recebiam a notícia de que uma pessoa havia desaparecido, logo, supostamente havia sido presa, iniciava-se uma movimentação em busca da identificação do local onde o referido indivíduo pudesse estar, a fim de garantir a sua integridade física. Essas notícias chegavam aos advogados como pedidos de socorro, lembrou Fragoso, que acrescentou:

Que podíamos fazer? Eram vários os órgãos que poderiam ter efetuado a prisão. Nenhuma informação obtínhamos, nem na polícia política, nem na Polícia do Exército, onde nem sequer podíamos entrar. O advogado só pode lutar com a lei e, nessa época, simplesmente não havia lei alguma que garantisse os direitos de liberdade do preso, porque não havia instrumentos processuais que permitissem reclamar a sua observância. O Ato Institucional no 5 suspendeu o "habeas corpus" e essa medida equivalia a virtual autorização para o constrangimento ilegal. $\mathrm{O}$ poder público atuava como atua os delinquentes (FRAGOSO, 1984, p. 146).

\footnotetext{
5 A Constituição de 1988 definiu que nenhuma pessoa seria submetida à tortura no Brasil. Depois da ditadura militar e das várias denúncias de sevícias praticadas em território nacional, esse foi um dos dispositivos constitucionais promulgados durante a redemocratização, mas que foi regulamentado, apenas, em 07 de abril de 1997, quando a Lei no 9.455, a Lei da Tortura, foi sancionada. Isso mostrou um grande hiato temporal entre o final do regime militar e a lei que criminalizava a tortura. Em seu artigo primeiro, o crime de tortura consiste em constranger alguém com emprego de violência ou grave ameaça, causando-lhe sofrimento físico ou mental com o fim de obter informação, declaração ou confissão. Essa prática, por sua vez, foi bastante empregada nas sessões de tortura que ocorriam no país, naquele período. Sobre a referida lei, ver: BRASIL. Presidência da República. Casa Civil. Lei no 9.455 de 07 de abril de 1997. Disponível em: <http://www.planalto.gov.br/ccivil_03/leis/L9455.htm>. Acesso em: 10 jul. 2019.
} 
Esses defensores tinham diante de si e do trabalho que desempenhavam uma série de óbices como a que foi declarada acima, em especial, no plano jurídico, a suspensão do habeas corpus, que era uma medida jurídica garantida pela Constituição e empregada para proteger cidadãos que tinham sua liberdade infringida. Na década de 1960, quando a medida legal considerada mais draconiana do Estado foi decretada, o Ato Institucional no 5 (AI - 5), a utilização do habeas corpus foi proibida e, com isso, limitou-se a atuação do advogado naquelas circunstâncias ${ }^{6}$.

Tendo o AI - 5 esse tipo de recurso, a meta do governo era intensificar a desarticulação da oposição civil e política e para que isso pudesse acontecer era preciso enfraquecer a defesa para atingir o inimigo causador da subversão. Não obstante, os advogados procuravam caminhos jurídicos que os levassem a contornar essa barreira legal e muitos continuavam a usá-lo, mas com a denominação de petição.

Conforme afirmou René Ariel Dotti, um dos advogados que atuou na defesa dos presos políticos da Operação Marumbi:

[...] de acordo com o caso, utiliza o habeas corpus ou o direito de petição. Para ele, o direito de petição era aludido pelos advogados contra o abuso de autoridade. Assim, outra possibilidade era, através da 'petição', solicitar a liberdade do preso, uma vez que a prisão não cumpria os prazos estipulados em lei (In: SPIELER; QUEIROZ, 2013, p. 45).

Mas também havia, no plano pessoal, problemas que os advogados enfrentavam devido ao seu comprometimento com a defesa de presos políticos. Mesmo que não declarassem publicamente nenhuma ideologia, havia uma forte intimidação e ameaça oriundas do Estado, afinal, vários advogados reconhecidos foram sequestrados. Fragoso, por exemplo, foi

\footnotetext{
6 Do ponto de vista teórico, um debate importante sobre essas questões, encontra-se em Agamben (2004). Em suas reflexões, o autor analisa o papel do Estado em um "regime de exceção", apontando para duas perspectivas: 1) uma "crise de linguagem" (a dualidade entre o discurso do direito e o discurso da justiça), e 2) um "estado de exceção" propriamente dito, como um espaço em que a lei fica em "suspenso" e onde tudo é possível (no caso da conjuntura brasileira aqui analisada, o poder nasce de um episódio político ilegal e que permite a este estado praticar crimes, colocando-se acima da lei).
} 
BRUNELO, L.; PRIORI, A. Resistência democrática versus graves violações dos direitos...

preso em novembro de 1970 e citou que outros colegas de profissão tiveram a mesma "sorte".

O objetivo dessas prisões era criar uma atmosfera de medo, pois não podiam ser acusados de nada, uma vez que, exclusivamente, exerciam a advocacia. Na prática, o resultado concreto dessas ações foi $o$ desencadeamento de uma postura mais dura e uniforme por parte da Ordem dos Advogados do Brasil $(\mathrm{OAB})^{7}$ em reivindicar o estabelecimento de um Estado Democrático, no qual os direitos dos cidadãos fossem assegurados.

No exercício da advocacia, diante de turbulências, os juristas, quando realizavam as defesas dos acusados, focavam em elencar as características nobres e positivas de seus clientes perante o Juiz. Era uma estratégia encontrada para apresentar o condenado ao Estado, pois essa medida ajudava o Juiz a presumir a capacidade de recuperação social do réu. Para Fragoso, as defesas criminais eram complexas, afinal, a pessoa em si era julgada, e não as relações jurídicas.

Como o julgamento se centrava no caráter do réu, o advogado tinha de ser hábil e demonstrar uma grande capacidade de compreender socialmente o seu cliente, a fim de ser exitoso em sua defesa perante o aparelho policial e judiciário do Estado, composto por um grande estrutura. O sistema da Justiça Militar ${ }^{8}$ brasileira era formado pelos agentes de segurança, encarregados de prender os acusados de cometerem crimes políticos, pelos Procuradores Civis do Ministério Público Militar, Juízes civis e militares que compunham o tribunal. O STM "era o tribunal militar de recursos, para onde eram encaminhados os casos julgados em primeira instância nos tribunais militares regionais. Acima do STM estava o Supremo Tribunal Federal, da justiça civil”' (PEREIRA, 2010, p. 127).

\footnotetext{
7 Sobre a Ordem dos Advogados do Brasil (OAB) remetemos ao próprio sítio da instituição na internet, que tem um pequeno histórico sobre suas origens e funções (ORDEM DOS ADVOGADOS DO BRASIL, 2019).

8 Com a vinda da família real portuguesa para o Brasil, no começo do século XIX, a Justiça Militar foi criada por meio do Alvará no 16. O Conselho Supremo Militar e de Justiça (CSMJ) era a instância máxima que julgava os processos criminais de acusados que possuíam foro militar. O CSMJ deu lugar ao Supremo Tribunal Militar, devido a promulgação do decreto no 149, em 1893. Com a Constituição de 1934, a denominação "Supremo" foi alterada para Superior Tribunal Militar, passando a integrar o Poder Judiciário na mesma época. Em 1920, a Justiça Militar passou a contar com a integração das Auditorias que funcionavam como primeira instância. No Estado Novo, o STM passou a receber recursos de processos que eram julgados pelo Tribunal de Segurança Nacional (TSN), que entrou em funcionamento em setembro de 1936 para apurar os crimes contra a Lei de Segurança Nacional. Deixou de fazer parte da Justiça Militar em dezembro de 1937. Sobre a história da Justiça Militar brasileira ver Silva (2013) e Guazzelli (2011).
} 
Diante desse aparato legal e institucional da ditadura militar, o trabalho dos advogados que atuaram ${ }^{9}$ no IPM 745 simbolizou uma resistência democrática e sinalizou que o Estado, mesmo cercado por dispositivos legais, não observou as leis, agiu com violência e desrespeitou os direitos dos presos políticos da Operação Marumbi.

Para René Ariel Dotti, o que se viu, após 1975, foi o recrudescimento das perseguições ideológicas que tinham como mote o combate e a aniquilação do comunismo.

[...] O radicalismo ideológico na investigação das supostas infrações políticas pode ser medido pela forma e pelo conteúdo do relatório elaborado pelo delegado Ozias Algauer ${ }^{10}$ ao longo das 53 (cinquenta e três) páginas datilografadas. A elaboração formal do relatório ${ }^{11}$ de conclusão do inquérito (encerrado em 10 de novembro de 1975), já demonstrava que a técnica de distribuição dos assuntos, a terminologia e a sintaxe apareciam como instrumentos de origem distinta dos formulários dos cartórios policiais rotineiros. Basta ver que através de um INTRÓITO se iniciava o trabalho de exposição com esse preciosismo acaciano: A Subversão foi, é, e sempre será uma constante entre os homens. A grafia da palavra subversão com inicial maiúscula já revela uma espécie de culto às avessas ao fenômeno, como se fosse possível diabolizar as palavras e ideias assim como se faz quando se as deificam (ARRUDA, 1983 , p. 13, grifos do autor).

9 Os advogados do IPM 745 foram: Luiz Salvador, Élio Narezi, Antônio Acyr Breda, Reginaldo Condessa Beltrami, Aurelino Mader Gonçalves, René Dotti, José Roberto Leal de Carvalho, Joel Gama Lobo d'Eça, Paulino Andreoli, Amilton Padilha, Duílio Giuseppe Melani, Fredi Humpreys, Antônio Alves do Prado Filho, Otto Luiz Sponholz, Fernando Ramos David João, Walter Borges Carneiro, Iberê Bandeira de Melo, Augusto Sussekind de Moraes Rêgo, Iguatemi Costa, Heráclito Sobral Pinto e Manuel de Jesus Soares.

10 Ozias Algauer era o responsável pela Delegacia de Ordem Política e Social (DOPS), órgão de segurança que ajudou a prender os militantes do PCB. Na DOPS, desenrolou-se a fase policial, na qual a apuração sumária dos fatos ocorreu. Sobre a história da DOPS/PR, ver Priori (2016).

11 O IPM corresponde a uma apuração sumária de fato que configure crime militar. Seu caráter é o de instrução provisória com a finalidade de reunir elementos para a propositura da ação penal. Quando reunidos, esses elementos (interrogatórios dos acusados, depoimentos de testemunhas, provas) dão origem a um relatório preparado pela autoridade policial encarregada, no qual indica as pessoas que devem ser processadas e qual a lei que deve ser aplicada ao caso em tela. Esse relatório é remetido à esfera da Justiça Militar, recebido pelo Ministério Público Militar (MPM), o qual instaura a fase processual (AQUINO, 1999). 
Além dos formulários distintos, que o advogado mencionou na entrevista de 1983, concedida ao jornal Folha de Londrina, o ano de 1975, de uma maneira geral, foi diferente, se considerarmos que a oposição estava sob controle e que o governo do General Presidente Ernesto Geisel almejava a distensão política, embora de viés autoritário. Essa discrepância entre o discurso do governo e as ações efetivas se deu mediante o recrudescimento da repressão, dessa vez, pontual e seletiva, e o aumento dos relatos de casos de tortura, se comparados com as ocorrências do ano de 1974 (GASPARI, 2014).

O governo militar estabeleceu um sistema eficiente de tutela penal que protegia os interesses daqueles que detinham o controle do poder, e ações políticas dissonantes eram reprimidas e incriminadas. Nesse caso, os direitos de manifestação e de expressão do indivíduo eram anulados e enfraquecia-se, também, a defesa política do cidadão perante o Estado. Isso acontecia porque:

[...] a garantia política do cidadão em face do poder punitivo do Estado, configura um obstáculo aos interesses do poder revolucionário, que pretende pôr o direito penal a serviço de sua causa, dirigindo a ameaça penal (quase sempre violenta, desproporcionada e odiosa) contra toda atividade que se oponha a revolução. A incriminação de "qualquer atividade contrarrevolucionária" conduz ao arbítrio, à prepotência e à tirania, pois a expressão, interpretada pelos detentores do poder, ou por juízes transformados em guardiões do Estado revolucionário (e não mais da lei e do direito), reduz o direito penal a mero instrumento de ação política (FRAGOSO, 1984, p. 4).

Com a nulificação das prerrogativas políticas, as pessoas, que eram consideradas perigosas pelo governo, eram as vítimas das ações repressivas que podiam ser extralegais, como ameaças, sequestros e execuções sumárias, mas, também, podiam ser legais e assentadas em um instrumental jurídico definido e claro, no entanto, arbitrário, como eram os IPMs.

Nesse sentido, resgatamos, novamente, as ideias do jurista Fragoso, que questionou a validade dos IPMs em certos aspectos: 
[...] IPMs abertos há mais de um ano prosseguiam vigorosamente e sem dar sinais de chegar ao fim. Isso, juridicamente, não tem sentido. Um inquérito faz-se para apurar um fato pretérito determinado, que se apresenta como delituoso e instaura-se em face de concreta notícia de crime. Alguns dos IPMs tinham objeto absolutamente vago e indeterminado (FRAGOSO, 1984, p. 10).

O nascimento do inquérito, quando permeado por falhas, era muito danoso, afinal, os problemas e a inconsistência jurídica se arrastavam para as próximas etapas e contaminavam o processo como um todo. Um IPM malnascido e que havia se sustentado em atos de sevícia merecia nulidade, contudo, essa regra podia ser considerada uma exceção no governo dos militares.

O trabalho dos advogados no IPM 745 tentou anulá-lo, uma vez que os presos revelaram em Juízo que foram torturados pela polícia política, mas o Ministério Público Militar (MPM) rebateu os argumentos apresentados durante os depoimentos judiciais e deu continuidade ao processo. Portanto, o substrato do arranjo legislativo não estava em sintonia com a obrigatoriedade de se respeitar os direitos e as garantias individuais, já que era harmônico com os propósitos punitivos dos militares e dos agentes da repressão.

Antes que a sentença fosse dada pelo Conselho Especial de Justiça para o Exército da 5a Circunscrição Judiciária Militar (CJM), tanto o MPM quanto os advogados de defesa elaboraram suas alegações finais com a intenção de fortalecer e de reverter as acusações que pairavam sobre os presos, respectivamente.

O documento que a Procuradoria do MPM preparou possuiu seis itens: 1) "a denúncia"; 2) "a materialidade e a autoria"; 3) "o elemento subjetivo"; 4) "a tipicidade"; 5) "a fixação das penas" e 6) "o pedido".

Sobre a denúncia, o destaque foi dado à tentativa de reorganizar o PCB no Paraná, o que era considerado crime político pela LSN. Sobre a materialidade e a autoria, a Procuradoria sublinhou o fato de os acusados terem confessado o crime que cometeram ao responsável pelo inquérito, entretanto, tentaram se desvencilhar das imputações dizendo em Juízo que foram torturados pela polícia e que as assinaturas que constavam nos 
inquéritos tinham sido obtidas por meio de pressões e de constrangimentos, além das sevícias já efetuadas.

Sobre o elemento subjetivo, o comportamento dos acusados foi pautado pelo "dolo direto e específico" (AEL, Projeto BNM. Processo 551, p. 4.861), ou seja, violaram a lei com pleno conhecimento da criminalidade praticada, além de demonstrarem a vontade livre e consciente de trabalharem em conjunto para reerguerem o PCB, ilegal desde 1948, portanto, "prejudicial" e "perigoso" à LSN. O fato de terem se comportado dessa maneira robusteceu a tipicidade do crime, que foi o de desobedecer ao que estava previsto no artigo 43 da LSN.

Diante do exposto, a Procuradoria apontou para a fixação das penas da seguinte maneira:

A pretensão punitiva irá obedecer a um critério inicial de solicitar a condenação de elementos que tenham participado de Comitês, ou Estaduais, ou Municipais do Partido Comunista Brasileiro no Paraná, sendo que, para o caso de C.M. é necessário que o elemento tenha pertencido à sua Direção Executiva e não simples membro ou responsável por OO. BB. (Organizações de Base) (AEL, Projeto BNM. Processo 551, p. 4.861).

As alegações dos advogados visavam rebater as afirmações da Procuradoria do MPM e desconstruir o potencial subversivo que era imputado aos presos políticos. No geral, o teor narrativo da documentação preparada pela defesa destacava que a qualificação de reorganizadores do PCB no Paraná, apontada pela Procuradoria, tinha sido feita a "esmo"; ausente, portanto, de rigor, logo, era "nebulosa", "débil" e "absurda".

A acusação feriu um item básico que era a isonomia processual, corolário do princípio constitucional, que garantia a igualdade de todos os indivíduos perante a lei, em especial, a "Lei Processual Militar". Essa referência ao universo legislativo militar, em princípio, parecia uma atitude incoerente, contudo, era uma artimanha empregada para sinalizar o comprometimento que o Estado possuía de proteger a sociedade e as pessoas, logo, os acusados em questão, que não haviam transgredido a 
LSN, de acordo com a defesa, mereciam ser colocados sob o teto da salvaguarda legal.

Para o advogado Reginaldo Condessa Beltrami:

[...] como poderão os ora acusados usar do DIREITO DE AMPLA DEFESA, também preceito constitucional se não existem fatos bem positivados para que seja feita a prova em contraditório, quando nem se quer se tem o argumento do local, hora e data certa para contrapor aquela imputação? (destaques presentes no documento) (AEL, Projeto BNM. Processo 551, p. 4.916).

Portanto, a "reorganização do partido" efetivamente não aconteceu e a acusação só atendia aos interesses da Procuradoria que, por sinal, queria insistentemente validá-la. Mas essa validação era carente de força e de sentido, uma vez que nenhuma prova substancial que atestasse algum crime cometido havia sido apresentada.

Os argumentos da defesa também contestaram os interrogatórios policiais que reuniram as confissões dos acusados: "[...] confissões essas obtidas mediante COAÇÃO E DIVERSAS ILEGALIDADES, as quais agora a Ilustrada Procuradoria procura nominar de INDEMONSTRADAS" (AEL, Projeto BNM. Processo 551, p. 4.917) (destaques presentes no documento).

Outros pontos defendidos pelos advogados se sustentavam na ideia-força de que a ação penal devia avaliar o fundamento da pretensão punitiva e não forçar uma situação ou um contexto que tornasse a punição concreta. Não obstante, não era isso que se presenciava no IPM 745, uma vez que o intuito era atribuir aos presos um crime político que não haviam cometido.

Para o jurista Joel Gama Lobo D'Eça, havia muitos trechos duvidosos e confusos nos inquéritos e, segundo sua visão, a polícia política não havia se preocupado em desvendar como, por exemplo: publicações comunistas que estavam em poder dos presos. Entretanto, o advogado questionou: quais publicações eram essas? Havia, também, a menção dos "pontos", locais de encontros entre os acusados e, novamente, a pergunta do advogado se fez: qual era o ponto no qual os incriminados se 
encontravam? Onde ficava? Quão intensa era a atividade comunista dos acusados? E, por fim, quem eram as pessoas aliciadas pelos acusados para fortalecer o comunismo no Paraná? (AEL, Projeto BNM. Processo 551).

Sendo assim, para que houvesse a certeza do cometimento do crime, algumas perguntas básicas precisavam ser respondidas, contudo, as confissões obtidas na DOPS, e que tinham um valor relevante para a Procuradoria, não ofereciam as respostas. Como essas dúvidas não eram sanadas nos interrogatórios, uma vez que as afirmações eram de natureza genérica e carentes de fundamentação, defendia-se que a denúncia era inepta e que o IPM 745, como um todo, devia ser anulado.

O IPM em pauta precisava ser invalidado porque havia ocorrido, também, uma falha no processo de constituição do Conselho Especial de Justiça, pois:

[...] houve preterição de formalidade essencial e substancial no que se refere ao sorteio e compromisso dos Juízes Militares, integrantes do Conselho Especial, qual seja a prevista no inciso III, alínea "H" do art. 500 do Código de Processo Penal Militar, de vez que é princípio jurídico o ato nulo gerar a nulidade dos que lhe são subsequentes (AEL, Projeto BNM. Processo 551, p. $4.940)^{12}$.

A formalidade preterida dizia respeito a não observância do artigo 403 do Código do Processo Penal Militar (CPPM), o qual afirmava que o acusado tinha o direito de assistir ao sorteio que formaria o Conselho Especial de Justiça, e essa garantia constitucional, não foi respeitada:

[...] não bastando a presença do advogado, uma vez que além da defesa técnica, profissional, existe aquela pessoal, íntima, intransferível e indispensável. Além de ser um direito do preso sua presença naquele ato, é uma decorrência da publicidade dos atos judiciais, de vez que não seria lógico, nem de direito e

12 No artigo 500 do CPPM, a alínea "H", refere-se justamente ao sorteio dos Juízes Militares e o compromisso que a partir de então eles deverão assumir. Esse artigo está inserido no Livro III - Das Nulidades e Recursos em Geral; Capítulo I - Das Nulidades (BRASIL, 1969a). 
muito menos justo, qualquer do povo assistisse dito sorteio (sic) ao passo que o mesmo direito fosse tolhido do réu, na verdade e justamente o maior interessado (AEL, Projeto BNM. Processo 551, p. 4.940).

Como os incriminados não assistiram ao sorteio dos conselheiros, logo, não puderam também fiscalizar o referido ato e a Justiça Militar ao proceder dessa forma, cerceando o direito das pessoas presas, feria a legislação, pois não atendia ao que estava previsto no CPPM.

O jurista Aurelino Mader Gonçalves, por sua vez, destacou que a leitura de um jornal comunista, o encontro com outra pessoa que também figurava como acusado no IPM 745 e ter contatado candidatos do Movimento Democrático Brasileiro (MDB), na época das eleições parlamentares de 1974, não eram crimes políticos.

Outro destaque foi a incongruência dos fatos presentes nos interrogatórios policiais e judiciais. O que se observou nos documentos do âmbito da DOPS e o que foi falado pelos acusados em Juízo nada tem a ver, eram afirmações opostas ${ }^{13}$.

A montagem dessas declarações no inquérito não se coaduna sequer, com a montagem feita para outras declarações dos demais codenunciados. É muito primária, principalmente se levarmos em conta que este acusado é pessoa de rara inteligência e bastante cultura [referência a Ildeu Manso Vieira]. Este acusado levaria em muita conta o seu instinto de conservação e não seria lógico atribuir-lhe uma confissão tão pormenorizada de fatos que nem tinha conhecimento, não fossem as sevícias de que foi vítima para assinar o que lhe mandavam (AEL, Projeto BNM. Processo 551, p. 5.371).

Um dos recursos dos advogados foi, também, basear-se no dado que se repetiu em várias falas dos presos políticos em Juízo, quer seja, a prática de tortura nos cárceres paranaenses. Além disso, outro subterfúgio

13 Sobre a comparação entre os interrogatórios, ver Brunelo (2009). 
BRUNELO, L.; PRIORI, A. Resistência democrática versus graves violações dos direitos...

era frisar que boa parte dos acusados não possuíam fortes vínculos com o $\mathrm{PCB}$, portanto, a defesa foi técnica e primou por não se envolver em celeumas de ordem política.

Não havia elementos fortes o suficiente para culpar, logo, pleiteava-se a absolvição, e as alegações finais da Procuradoria não apresentaram "a base ou a prova para convicção da culpabilidade", o que denotou inconsistência "jurídica e nem forma legal, fugindo completamente do que estabelece o Código de Processo Penal Militar e a Lei de Segurança Nacional" (AEL, Projeto BNM. Processo 551, p. 5.372).

O advogado Luiz Salvador pautou as suas ideias no enaltecimento das normas penais e enfatizou que a eficácia delas dependia de condutas e de ações jurídicas íntegras, em especial, de um processo válido que garantisse o princípio do contraditório e da ampla defesa.

O IPM 745 não estava em consonância com essas prerrogativas, uma vez que as irregularidades processuais que haviam se manifestado até o momento eram de natureza insanável, ou seja, "aquelas consequentes de desatenção à regra necessária à validade do que se fez, trazendo vícios irremovíveis, que resultam na invalidade do ato" (AEL, Projeto BNM. Processo 551, p. 5.037).

Irregularidades insanáveis provocavam a nulidade processual e foi com essa tese que Salvador iniciou as alegações finais. Junto ao mote principal, o advogado agregou vários pontos que fortaleciam a sua ideia inicial, dentre eles, o descumprimento da Constituição Federal, pois, segundo o que constava no texto constitucional ${ }^{14}$, era de competência da Polícia Federal apurar os crimes contra a Segurança Nacional e de Ordem Política e Social. Essa função não cabia a um órgão estadual, uma vez que a lei ordinária era clara em sua orientação. Portanto, "a nulidade do Inquérito Policial [era provocada] em face da incompetência do DOPS" (AEL, Projeto BNM. Processo 551, p. 5.037).

Sendo assim, destacou-se a incompatibilidade entre as ações do Estado e o conjunto de leis fundamentais e constitucionais, que desabonavam o comportamento institucional, assinalando que a

14 Conforme a Emenda no 1, de 1969, no Título I: Da Organização Nacional - Capítulo I: Disposições Preliminares; artigo 8, compete à União, no inciso VIII: organizar e manter a polícia federal com a finalidade de: alínea "c": "apurar infrações penais contra a segurança nacional, a ordem política e social ou em detrimento de bens, serviços e interesses da União, assim como outras infrações cuja prática tenha repercussão interestadual e exija repressão uniforme, segundo se dispuser em lei” (BRASIL, 1969b). 
irregularidade estava presente desde o início do processo, pois "em prejuízo da defesa, a denúncia não é precisa na narração, quanto ao tempo, lugar do delito e exposição do fato com todas as suas circunstâncias, e tampouco quanto à classificação do crime, deixando, assim, de atender as exigências legais" (AEL, Projeto BNM. Processo 551, p. 5.038).

Como não atendia ao que previa a legislação, sobretudo o CPPM, a denúncia era nula. Consoante a isso, o que se apontava como crime político não feria o artigo 43, e os presos não eram de alta periculosidade para 0 Estado e a Segurança Nacional.

O Estado, representado pelo MPM, também foi omisso quando soube das torturas praticadas dentro das prisões paranaenses, denunciadas pelos presos da Operação Marumbi, e não tomou nenhuma medida para apurar as informações. Por isso, o advogado Luiz Salvador relembrou a função social e legal do órgão público: "no seu papel de fiscalizador do cumprimento da ordem legal, tem a obrigação de diligenciar no sentido das providências cabíveis à descoberta da verdade real, ao tomar conhecimento de eventual notitia criminis" (AEL, Projeto BNM. Processo 551, p. 5.045).

A notícia das sevícias era grave e feria o artigo 153 da Constituição ${ }^{15}$, portanto, era preciso que o MPM instaurasse um inquérito para que os fatos fossem apurados. Não obstante, a ação tomada pelo órgão público foi outra, diametralmente oposta, pois:

Ao invés de abertura de competente inquérito, no momento apropriado, silenciou, vindo agora em suas alegações finais, alegar que já está acostumado a ouvir tais tipos de acusações em processos políticos e que a responsabilidade pela prova do alegado, cabia aos acusados e nada provaram. Nada mais ridículo! Onde a justeza e a parcialidade do Órgão do Ministério Público? Como os acusados diante da situação a que se deparavam, inertes e inermes, inclusive, estiveram incomunicáveis por vários dias e após recolhidos à prisão? (AEL, Projeto BNM. Processo 551, p. 5.045).

15 No artigo 153 da Constituição (Emenda Constitucional no 1 de 1969), em seu parágrafo 14, havia a prescrição de assegurar a integridade física e moral do detento. 
A falha jurídica apontada era séria, e agregada às demais, feria as leis pertinentes, o que invalidava o IPM. Por isso, o mote das argumentações da defesa se pautou nos vários problemas que cercaram o andamento do inquérito, sobretudo as torturas que os presos sofreram e que foram desconsideradas pelo MPM.

Dessa maneira, por meio de uma narrativa articulada, os advogados procuravam desconstruir as alegações do Estado, apresentando os problemas que cercaram o IPM desde o seu início. Principalmente, as torturas que ocorreram na DOPS e também no Destacamento de Operações e Informações - Centro de Operações e Defesa Interna (DOI - Codi), outro órgão de segurança interna que agiu durante a Operação Marumbi.

As falhas se apresentaram desde a fase policial e continuaram presentes na fase judicial, quando os presos não puderam participar do sorteio do Conselho de Justiça, do valor atribuído pela Procuradoria do MPM aos interrogatórios policiais, obtidos sob coação e violência, bem como pelo desprezo do próprio MPM em apurar as informações sobre a existência de tortura nas prisões paranaenses enquanto os presos políticos aguardavam os seus julgamentos.

\section{O comportamento da $O A B$, enquanto entidade de classe, durante a ditadura militar}

O Estado agia, reprimia e matava os militantes políticos de esquerda. Quando não matava, submetia-os a um estado de cárcere, como vimos no Paraná, com os militantes do $\mathrm{PCB}$, que tinham o seu direito à defesa cerceados, pois os advogados eram impedidos de acompanhar os seus clientes durante os interrogatórios na DOPS. O acesso aos autos de qualificação e de interrogatório também era dificultado, quando não, proibido, e a incomunicabilidade com o preso era outro fator que tornava o trabalho advocatício ainda mais complexo.

Entretanto, a despeito das dificuldades existentes e da tentativa do governo militar em restringir o campo de ação jurídica, os advogados e os familiares dos presos políticos foram os responsáveis por criar uma espécie de rede de solidariedade, pois do contato entre a família do preso e o 
defensor se criava uma atmosfera política de conscientização pública a respeito das prisões políticas e seus efeitos, além de contribuir para o fortalecimento das lutas em prol do respeito aos direitos humanos (TELLES, 2013).

Os advogados que desempenharam as suas funções durante a ditadura militar contribuíram para desnudar as arbitrariedades políticas que eram cometidas, quebrando, assim, o silêncio que até então dominava, o que fazia com que as leis de exceção fossem revertidas para proteger, quando possível, os seus clientes presos. Portanto, os causídicos denunciavam casos de abusos dentro dos cárceres, representavam a voz dos marginalizados políticos em situação de risco e se calcavam juridicamente na própria parafernália legislativa institucionalizada pelo Estado. compunha:

Conforme Janaína de Almeida Telles, o grupo de advogados

[...] um conjunto ideológico relativamente heterogêneo, composto de indivíduos ligados à esquerda, mas sem ligação orgânica com os partidos clandestinos, e de liberais, alguns dos quais inspirados por componentes religiosos. Alguns se tornaram políticos profissionais, mas em geral não tinham militância partidária. Havia respeito mútuo e troca de informações entre eles, mas não atuavam como um grupo organizado (TELLES, 2013, p. 6).

A Ordem dos Advogados do Brasil (OAB), entidade de classe dos advogados, hipotecou durante o golpe civil-militar uma grande parcela de solidariedade, de energia e de expectativa para o evento político que depôs o presidente da República, acreditando que a democracia brasileira, a partir daquele momento, tomaria outros rumos que a distanciariam da subversão e de uma possível comunização. Ou seja, a OAB apoiou e participou do golpe.

Entretanto, conforme sublinhou Denise Rollemberg (2008), a $\mathrm{OAB}$, na década de 1970, repensou o seu apoio ao governo e redefiniu a sua perspectiva em relação aos desdobramentos políticos e sociais inaugurados após 1964. A entidade que se colocou do lado da nova autoridade do país e que ansiava pela ordem coletiva e paz social, adotando 
BRUNELO, L.; PRIORI, A. Resistência democrática versus graves violações dos direitos...

a clássica bandeira do anticomunismo da época, deixando de lado essa postura e passando a enfrentar o regime militar.

Contudo, os atos de repensar e de redefinir sua posição em relação ao Estado não estavam vinculados ao golpe em si, desfechado em 1964. Havia uma diferença de pensamento entre o golpe, visto como "Revolução", e os rumos que o governo militar veio a tomar depois. Para Rollemberg:

[...] na documentação das atas, registro de posições individuais, de grupos e da Instituição, é evidente a identidade da OAB com a cultura política de direita que estruturou as forças civis na derrubada do governo eleito democraticamente. Essas instituições, mais do que apoiarem o golpe, dele participaram. $\mathrm{A} \mathrm{OAB}$ não redefiniu sua posição quanto ao golpe. A maneira como viu os primeiros anos da década de 1960, o governo Goulart e a participação popular na defesa das reformas não mudou nos anos seguintes. Julgou na época a necessidade da intervenção militar [...]. O que veio depois nada tinha a ver com a revolução na qual a Ordem se engajara. Essa - a revolução permaneceu intocável, imaculada. $\mathrm{O}$ abismo entre o golpe e a ditadura (ROLLEMBERG, 2008, p. 31, grifos da autora).

O abismo que se abriu entre o golpe defendido pela entidade e a ditadura militar apresentou uma outra maneira de se relacionar com os dirigentes do poder, pois a $\mathrm{OAB}$ e demais grupos, como aqueles representados pela Conferência Nacional dos Bispos do Brasil (CNBB) e Associação Brasileira de Imprensa (ABI), passaram a representar importantes focos de resistência democrática contra o regime político.

Para Paula Spieler e Rafael Mafei Rabelo Queiroz, com a promulgação do $\mathrm{AI}-5$ e o aumento da violência institucionalizada:

[...] a OAB passou a adotar um tom de contraponto mais forte às iniciativas do regime. Viu-se que a violência dos primeiros meses do governo militar não era passageira, como muitos esperavam; ao contrário, seu viés era de alta, como também se perdia de vista a perspectiva de sua duração, nos ecos da 
retórica governista da 'revolução permanente que legitima a si mesma' - e que se permitia utilizar da força necessária para seguir em seu 'intento transformador'. Quando Raimundo Faoro tornou-se presidente do Conselho Federal da OAB, em 1977, o órgão contaminou-se de vez com o espírito da oposição e tornou-se um importante ator na luta pela redemocratização, aliado a outras organizações da sociedade civil. Embora em cenários regionais a postura dos órgãos de classe dos advogados possa ter sido diferente, foi lenta a tomada de posição política antirregime no nível federal (SPIELER; QUEIROZ, 2013, p. 34).

O posicionamento declarado da instituição só veio à tona a partir de 1972, quando a Ordem realizou o VI Encontro da Diretoria do Conselho Federal, em Curitiba. Desse evento, formulou-se a Declaração de Curitiba que:

[...] firmou a $\mathrm{OAB}$ no campo da luta pela redemocratização. Nele, a defesa do restabelecimento das garantias do Judiciário e da plenitude do habeas corpus; da "harmonia entre a segurança do Estado e os direitos do indivíduo, na conformidade dos princípios superiores da Justiça"; do "livre exercício da atividade profissional do advogado; do respeito à pessoa humana; dos princípios da Declaração Universal dos Direitos do Homem (ROLLEMBERG, 2008, p. 29).

Em 1974, quando a entidade de classe realizou a V Conferência dos Advogados, no Rio de Janeiro, batizou-a de "O advogado e os direitos do homem", uma vez que os trabalhos apresentados e as discussões que se realizaram versaram sobre esse tema. Conforme foi registrado pelo Jornal do Brasil, o presidente da $\mathrm{OAB}$, na ocasião, chamou a atenção para o descumprimento dos direitos garantidos aos cidadãos:

O presidente da Ordem dos Advogados do Brasil, Sr. José Ribeiro de Castro Filho, afirmou ontem que os Direitos Fundamentais da Pessoa Humana - tema que será tratado na $\mathrm{V}$ 
Conferência dos Advogados - não se restringe hoje apenas ao direito de defesa, de vida e de liberdade, mas também ao direito de educação, de trabalho e de bem estar social. Segundo o Sr. Ribeiro de Castro Filho, a Declaração Universal dos Direitos da Pessoa Humana da ONU, apesar de estar incluída em todas as Constituições e tratados internacionais, continua sendo violada de uma maneira geral não só no Brasil, mas em todo o mundo. E, na maioria das vezes, estas violações partem do próprio Poder Executivo ou, pelo menos, com a sua cumplicidade (JORNAL DO BRASIL, 1974).

A fala do representante da $\mathrm{OAB}$ destacou o que incomodava os membros da ordem naquelas circunstâncias, sobretudo as restrições e as violações dos direitos garantidos às pessoas. A insatisfação com a política dos Generais Presidentes adquiriu, a partir de então, maior substância e ecoou nas diretorias que se constituíram após 1970.

A presidência da Ordem, à frente do biênio 1975 - 1977, frisou a continuação do trabalho em prol da manutenção dos direitos dos cidadãos, bem como das garantias constitucionais, além de lutar pelo restabelecimento do habeas corpus. Dentre um dos atos que ocorreu durante a posse da nova diretoria da $\mathrm{OAB}$, houve a entrega de um relatório elaborado por José Ribeiro de Castro Filho, no qual ele salientou as principais ações tomadas durante o seu período à frente da entidade (1972 1974).

Conforme noticiado pelo Jornal do Brasil:

O relatório lembra que em março do ano passado [1974], a Ordem se manifestou sobre "os riscos da advocacia", ao denunciar violências sofridas por advogados nas atividades de sua profissão. Continua o documento: "nós nos opomos sistematicamente ao crime em todas as suas formas e modalidades de manifestação, até porque é ele a negação da juridicidade, mas sustentamos, apesar dos riscos que são muitos, o direito de defesa do criminoso" (JORNAL DO BRASIL, 1975a). 
A prática da violência era um tipo de barreira que se colocava diante do exercício do trabalho advocatício, pois era uma forma de o Estado pressionar e disseminar o medo junto àqueles que questionavam a estrutura legal.

Podemos destacar que nesse período, final dos anos de 1960 e primeira metade da década de 1970, como observou Maria Helena Moreira Alves (2005), as ondas de violência e de repressão eram muito fortes e, inclusive, organismos internacionais religiosos e de direitos humanos recebiam denúncias sobre a existência de lugares secretos onde se praticava tortura no Brasil e onde, também, presos políticos desapareciam.

De uma maneira geral, os atos violentos do Estado criaram uma espécie de cultura do medo que:

[...] tinha três importantes componentes psicológicos: o primeiro era o silêncio imposto à sociedade pela rigorosa censura de todos os veículos de informação e o fechamento de alguns destes. As universidades eram controladas, e o teatro, o cinema, a música, a literatura, as artes e a cultura em geral deviam submeter-se à censura para obter dos militares autorização para chegar ao público. Com censores fisicamente presentes nos estúdios e redações, e dispositivos de censura rigidamente aplicados, os veículos de comunicação foram silenciados, impedindo-se a divulgação ou discussão das consequências das políticas econômicas ou repressivas do governo. A população sabia, assim, da existência da repressão, e experimentava a realidade da violência institucionalizada de Estado, mas não podia manifestar seu medo ou protestar publicamente. Este silêncio imposto, por sua vez, provocou profundo sentimento de isolamento naqueles que sofriam diretamente a repressão e/ou exploração econômica [...]. Finalmente, como consequência das duas outras características da cultura do medo, generalizou-se a crença de que todos os canais de oposição estavam fechados e nenhuma iniciativa poderia ter resultados efetivos. Parecia impossível enfrentar o poder do Estado. Um sentimento de total desesperança passou a prevalecer na sociedade, mantendo - mais talvez que qualquer outra coisa - o clima de retraimento da atividade de oposição (ALVES, 2005, p. 205 grifos da autora). 
Mesmo que a cultura do medo estivesse disseminada junto à sociedade e que as investidas repressivas do Estado fossem realizadas de forma austera e sistemática contra a oposição política, grupos sociais ou entidades, como a OAB, posicionavam-se diante das ações abusivas, inerentes às práticas do governo militar.

A diretoria do biênio 1975-1977 encaminhou ao General Presidente Ernesto Geisel um documento que externava o mal-estar em relação ao clima de violência presente no país. Segundo o Jornal do Brasil, que publicou uma nota em 23 de julho de 1975, o Conselho Federal da OAB decidiu:

[...] por unanimidade, enviar memorando ao Presidente Geisel, denunciando todas as violências praticadas não só contra advogados, mas contra os cidadãos de modo geral. O documento será redigido pelo advogado Caio Mario da Silva Pereira, presidente do Conselho [...]. Inicialmente, o professor Caio Mario da Silva Pereira comunicou aos presentes à reunião do Conselho Federal da OAB já ter enviado ao Ministro da Justiça, Sr. Armando Falcão, ofício solicitando que cessassem as prisões irregulares de advogados em vários pontos do país [...]. Para o professor Heleno Fragoso o documento a ser enviado deverá ser rigoroso, ponderado e sereno. Mas deverá mostrar que a tortura continua sendo rotina na investigação criminal no Brasil (JORNAL DO BRASIL, 1975b).

A observação do jurista Heleno Cláudio Fragoso atestou uma prática constante nas prisões efetuadas durante a ditadura militar. No Paraná, as detenções dos militantes do PCB realizadas pela Operação Marumbi foram feitas à base de violência, e nos órgãos de segurança, DOPS e DOI-Codi, a tortura era utilizada quando os presos eram interrogados.

Uma das principais utilidades da tortura era forçar os presos a darem informações que interessavam à polícia política, uma vez que entre os integrantes do grupo de oposição havia a troca de informações, discussões diversas em relação a questões internas do partido ou externas, referentes à política nacional e internacional. Qualquer dado obtido, que 
versasse sobre o PCB, no caso, ou que incriminasse outras pessoas, envolvendo-as com o comunismo, era importante para os torturadores.

Como frisou Marta Knisely Huggins, referindo-se sobre a existência da tortura durante a ditadura militar brasileira, que era realizada das mais variadas e sofisticadas formas:

[...] não poderia ter continuado - particularmente ao se defrontar com uma crescente condenação internacional - não fosse a imposição forçada do silêncio. Conseguiu-se isso através de uma rede bem articulada de relações, que incluía os próprios torturadores, os médicos e psiquiatras que atestavam que determinada vítima não fora torturada, ou até mesmo ajudavam durante a tortura, os escrivães e escriturários que deixavam de registrar ou declaradamente falsificavam as condições de uma vítima (HUGGINS, 1998, p. 202-203).

A sevícia, o cárcere privado, a execução sumária, os desaparecimentos de pessoas, os "métodos amparados na legislação (como a instauração de inquéritos policiais) e também a produção e armazenamento de uma quantidade enorme de informações sobre cidadãos considerados 'perigosos' para a ordem vigente" (AQUINO, 2001, p. 24) eram presentes no cotidiano político do Brasil, o qual viu, a partir de 1970, a organização de setores sociais que se colocaram diante do Estado para questionar os abusos cometidos contra os direitos e garantias individuais.

No Paraná, em 1975, a Associação dos Advogados de Londrina se reuniu em outubro para formular um documento que pedia esclarecimentos acerca das prisões de colegas durante a Operação Marumbi. Uma nota da Folha de Londrina assim registrou o evento:

A Associação dos Advogados de Londrina enviará dois telegramas e dois ofícios aos órgãos federais de segurança, pedindo informações e esclarecimentos sobre a prisão de quatro advogados londrinenses, ocorridas nos últimos 40 dias. A decisão foi tomada ontem em reunião, na sede da entidade [...]. Mensagens serão enviadas também à Ordem dos Advogados do Brasil, seção do Paraná, e ao presidente do Conselho Federal da 
OAB, Caio Mario da Silva Pereira, solidarizando-se com essas entidades na posição assumida em face das prisões [...]. As principais objeções foram feitas em relação à maneira como as prisões estão sendo efetuadas. Os advogados defenderam a tese de que elas devem ser feitas de maneira legal, e que haja comunicação à família ou à Associação (FOLHA DE LONDRINA, 1975, p. 5).

Os advogados presos pelos órgãos de segurança foram: Luiz Gonzaga Ferreira, presidente do Diretório do MDB de Londrina; Flávio Ribeiro e Almir Passos, da cidade de Londrina; e Arno André Gielsen, de Rolândia.

$\mathrm{O}$ ato da entidade de Londrina enfocou, sobretudo, a cobrança de esclarecimentos sobre o que havia acontecido com os seus membros, advogados paranaenses presos pela operação policial-militar de 1975 e serviu para publicizar a forma como as prisões eram efetuadas, muitas vezes, sem o respeito à lei e à dignidade humana.

\section{Considerações finais}

Como vimos ao longo deste artigo, com o golpe civil-militar de 1964 e a instauração de uma ditadura militar no Brasil, as pessoas tiveram seus direitos civis e políticos privados. $\mathrm{O}$ fim da eleição para presidente e para governadores, o fechamento do Congresso Nacional e uma intensa repressão aos movimentos sociais e políticos foram algumas medidas com forte impacto na sociedade brasileira. Assassinatos, desaparecimentos forçados, prisões, exílios dos adversários dos militares, o fim do direito ao habeas corpus e a instituição da tortura como uma política subterrânea do Estado foram medidas gravíssimas de violações contra os direitos humanos.

Essas violações são condenadas pelos tratados internacionais de Direitos Humanos, das quais o Brasil é signatário (PRIORI; KISCHENER, 2019, p. 19) e podem ser consideradas como "crimes contra a 
humanidade"16, principalmente pela utilização da tortura, pelo desaparecimento forçado e pela perseguição política. Ademais, essas graves violações foram perpetradas por agentes do Estado Brasileiro ou por meio do seu comando, contra a população civil, de maneira intensa e continuada.

Durante a ditadura militar (mas, também, em outros períodos da história brasileira, é bom que se diga) foram recorrentes os atos de graves violações contra os direitos humanos, tais como o uso permanente da força, a supressão dos direitos individuais e coletivos, o controle da liberdade de expressão, a imposição de um conjunto normativo autoritário - que visava institucionalizar e legalizar atos e práticas típicas de regimes de exceção -. a incomunicabilidade dos presos, a tortura, a violência sexual e a condenação sem provas substanciais ${ }^{17}$.

Todo esse processo foi levado a cabo a partir de um sistema paralelo de combate aos opositores do regime, com a obtenção de confissões e produção de provas forjadas sob tortura, sequestro e desaparecimento forçado e na pena capital, via de regra executadas à margem do sistema legal, de maneira clandestina e transladadas para o sistema normativo oficial, como vimos no exemplo do Inquérito Policial Militar n⿳⺈. 745.

O golpe civil-militar de 1964 almejou se defender diante dos grupos políticos divergentes e, por isso, transformou o Direito e, sobretudo, o Direito Penal, numa espécie de instrumento de ação política e punitiva. A jurisdição estatal se muniu de uma estrutura legal para garantir que o processo político fosse levado adiante a partir de referências jurídicas que atestassem a legalidade presente nas ações tomadas naquelas circunstâncias. Estamos falando dos atos institucionais, de uma nova Constituição, da abertura de IPMs, dentre outros dispositivos colocados em curso na sociedade.

A vocação legalista das Forças Armadas visava obter legitimidade, o que não significava simplesmente fazer com que os cidadãos obedecessem ao governo, mas o processo ali instalado era mais abrangente,

16 Crimes contra a humanidade implicam "a colocação em prática de uma política estatal de perseguição sistemática a um determinado grupo humano" (SILVA FILHO, 2012, p. 49).

17 Esses acontecimentos são bastante conhecidos pela historiografia brasileira, nas mais diversas contribuições de pesquisas realizadas nos últimos anos. Mas devemos registrar que foi importante o trabalho da Comissão Nacional da Verdade (CNV) e das diversas Comissões Estaduais da Verdade (CEVs), que não só elucidaram muitos dessas graves violações contra os direitos humanos, mas, mesmo que tardia e simbolicamente, tornaram-se documentos oficiais de reconhecimento destes atos pelo Estado brasileiro. 
uma vez que mirava na construção de uma sociedade plasmada por uma ordem objetiva e que também se manifestava subjetivamente, por meio da inculcação e da introjeção de valores, de ideias e de mitos.

$\mathrm{Na}$ ótica dos militares, o golpe civil-militar foi uma "revolução" que se saiu vitoriosa pelo fato de representar o interesse da nação e, com isso, passar a imagem de um governo que firmava um compromisso social e garantia a manutenção da democracia. Porém, o processo histórico não demorou a mostrar que se tratava de um simples arremedo democrático. Não obstante, mesmo que fosse uma imitação deficiente de um governo democrático, era sustentado por um arcabouço político-jurídico que abria espaço para que a oposição consentida aparecesse, e permitia, ainda que precariamente, o funcionamento parlamentar.

Isso demonstrava que o governo pensava ser fundamental controlar o poder político para levar adiante a consolidação do Estado Autoritário. Esse controle, por sua vez, ocorria por meio da composição e da execução de leis e da institucionalização de organismos políticos e jurídicos, voltados para a coação sociopolítica, econômica e cultural.

Foi com o poder político que os advogados de defesa dos presos no Paraná, em 1975, tiveram que lidar. A luta que se travou com o Estado, representado pelo poder Judiciário, foi orientada por pressupostos legalistas, pois ambos os lados, Estado e causídicos, apoiaram-se na legislação vigente para embasarem as suas argumentações.

Mesmo diante do esforço advocatício, representado pelas narrativas mostradas nas alegações finais, o Conselho Especial de Justiça da $5^{\mathrm{a}} \mathrm{CJM}$ puniu as pessoas presas pela Operação Marumbi com penas que variaram de 2 a 5 anos de reclusão. Isso mostrou que a ditadura militar brasileira teve um forte traço de judicialização, o que não significa afirmar que a repressão e o cerceamento políticos que ocorreram devem ser relativizados. O propósito apresentado foi o de exemplificar as ações jurídicas formuladas que atingiam os adversários ideológicos.

Além disso, o Estado quis aplicar a punição que era prevista pela LSN sobre a tentativa de reorganizar o partido político proscrito. Os advogados, por sua vez, também sustentados em referenciais legais, dentro do que era possível fazer no espaço judicial limitado, procuravam atribuir à Lei de Segurança Nacional um viés democrático e equilibrado.

A disputa ocorria entre dois agentes que possuíam forças muito díspares, não obstante, diante dessa desigualdade, os advogados - as figuras mais frágeis do processo de contenda travado com o Estado - valiam-se das 
competências que estavam ao alcance para positivar possibilidades que inviabilizassem uma punição, e, por isso, esforçavam-se em explorar as fórmulas jurídicas que permitiam trabalhar com as ambiguidades, com as lacunas e até mesmo com as contradições presentes, visando, sobremaneira, estimular a elasticidade da lei e do aparato jurídico-legal como um todo.

Portanto, o sistema jurídico da ditadura militar era, sem correr o risco de mitigar aspectos negativos intrínsecos ao governo, flexível, sem deixar de ser, concomitantemente, arbitrário na medida em que havia uma exígua separação entre os poderes, o que facultava ao Executivo, particularmente, a possibilidade de alterar os encaminhamentos do jogo político.

Representados por uma entidade que defendeu o golpe em 1964 mas que ao longo do percurso identificou os problemas do governo e os excessos políticos cometidos que dificultavam o trabalho dos juristas, que prendiam e matavam pessoas por pensarem diferente - os advogados e a OAB, sobretudo a partir da década de 1970, realizaram ações que objetivavam remexer com as interpretações jurídicas, a fim de proteger os direitos de vários presos políticos e, com isso, garantir a vida a essas pessoas frente à tortura e aos maus tratos da ditadura militar.

\section{Referências}

AEL. Projeto BNM. Processo n ${ }^{\circ} 551$.

AGAMBEN, Giorgio. Estado de exceção. Trad. Iraci D. Poleti. São Paulo: Boitempo, 2004.

ALVES, Maria Helena Moreira. Estado e oposição no Brasil: 1964-1984. Bauru: EDUSC, 2005.

AQUINO, Maria Aparecida de. et. al. (org.). No coração das trevas: o DEOPS/SP visto por dentro. São Paulo: Imprensa Oficial, 2001.

AQUINO, Maria Aparecida de. Imprensa e sociedade: experiências com a Justiça Militar (1964-1979). In: Anais do XX Simpósio Nacional de História - ANPUH. Florianópolis, jul. 1999, p. 545-553. Disponível em: 
BRUNELO, L.; PRIORI, A. Resistência democrática versus graves violações dos direitos...

<https://anpuh.org.br/uploads/anais-simposios/pdf/2019-

01/1547483138_5e0486f4ae55480990f222cff84ead34.pdf>. Acesso em: 12 jul. 2019.

ARQUIDIOCESE DE SÃO PAULO. Brasil: nunca mais. Petrópolis, Vozes, 1985.

ARRUDA, João. Prisão. Folha de Londrina. Londrina, 18 maio 1983. Cadernos Repressão, p. 13.

BOBBIO, Norberto; et. al. Dicionário de política. Brasília: Editora Universidade de Brasília: São Paulo: Imprensa Oficial do Estado de São Paulo, 2000.

BRASIL. Câmara dos Deputados. Emenda Constitucional $n^{o} 1$, de 1969 b. Disponível em: <http://www2.camara.leg.br/legin/fed/emecon/19601969/emendaconstitucional-1-17-outubro-1969-364989-publicacaooriginal-1pl.html>. Acesso em: 12 jul. 2019.

BRASIL. Presidência da República. Casa Civil. Constituição da República Federativa do Brasil de $1988 . \quad$ Disponível em: <http://www.planalto.gov.br/ccivil_03/constituicao/constituicaocompilado.htm>. Acesso em: 10 jul. 2019.

BRASIL. Presidência da República. Casa Civil. Decreto - Lei $n^{\circ} 1.002$, de 21 de outubro de 1969a. Disponível em: <http://www.planalto.gov.br/ccivil_03/decretolei/Del1002.htm>. Acesso em: 10 jul. 2019.

BRASIL. Presidência da República. Casa Civil. Lei no 9.455 de 07 de abril de 1997. Disponível em: <http://www.planalto.gov.br/ccivil_03/leis/L9455.htm>. Acesso em: 10 jul. 2019.

BRUNELO, Leandro. Legalidade e legitimidade durante a ditadura militar: o embate entre as estratégias legais de condenação e de resistência no IPM 745, instaurado no Paraná em 1975. Maringá, 2019. Tese (Doutorado em História) Universidade Estadual de Maringá, 2019.

BRUNELO, Leandro. Repressão política durante o regime militar no Paraná: o caso da Operação Marumbi na terra das araucárias. Maringá: Eduem, 2009.

CHIRIO, Maud. A política nos quartéis: revolta e protestos de oficiais na ditadura militar brasileira. Trad. André Telles. Rio de Janeiro: Zahar, 2012.

FOLHA DE LONDRINA. Associação dos advogados pede informações sobre prisão de quatro colegas. Londrina, 22 out. 1975. Caderno Política/Segurança, p. 5. 
FRAGOSO, Heleno Cláudio. Advocacia da liberdade: a defesa nos processos políticos. Rio de Janeiro: Forense, 1984.

GALLO, Carlos Artur. Memória, verdade, justiça e direitos humanos: um estudo sobre as relações entre o Direito e a memória da Ditadura Civil-Militar no Brasil. Plural. São Paulo, v.1, p. 31-48, 2014.

GASPARI, Elio. O sacerdote e o feiticeiro: a ditadura encurralada. Rio de Janeiro: Intrínseca, 2014.

GUAZZELLI, Dante Guimaraens. A Justiça Militar na ditadura civil-militar e os advogados. In: A lei era a espada: a atuação do advogado Eloar Guazzelli na Justiça Militar (1964-1979). Porto Alegre, 2011. Dissertação (Mestrado em História) - Universidade Federal do Rio Grande do Sul, 2011, p. 3747.

HUGGINS, Marta K. Polícia e política: relações Estados Unidos/América Latina. Trad. Lólio L. de Oliveira. São Paulo: Cortez, 1998.

IPÓLITO, Veronica Karina. O vermelho que violenta a ordem: os comunistas sob o olhar do DOPS no Paraná. Assis, 2016. Tese (Doutorado em História) - Unesp, Assis, 2016.

JORNAL DO BRASIL. Direitos do homem será tema de reunião da OAB. Rio de Janeiro, 26 jul. $1974 . \quad$ Disponível em: <https://www.news.google.com/newspapers?nid=0qX8s2k1IRwC\&dat=19740726 \&printsec=frontpage \&hl=pt-BR>. Acesso em: 11 jul. 2019.

JORNAL DO BRASIL. Novo presidente da Ordem dos Advogados enumera as metas ao assumir o cargo. Rio de Janeiro, 2 abr. 1975a, Caderno A1, p. 20. Disponível

em: <https://news.google.com/newspapers?nid=0qX8s2k1IRwC\&dat=19750402\&pr intsec=frontpage $\&$ hl=pt-BR $>$. Acesso em: 12 jul. 2019.

JORNAL DO BRASIL. Violências levam OAB até Geisel. Rio de Janeiro, 23 jul. 1975b, Caderno A1, p. $26 . \quad$ Disponível em: <https://news.google.com/newspapers?nid=0qX8s2k1IRwC\&dat=19750723\&prints ec=frontpage \&hl=pt-BR>. Acesso em: 11 jul. 2019.

KELSEN, Hans. Teoria pura do Direito. Trad. João Baptista Machado. São Paulo: Martins Fontes, 1999. 
BRUNELO, L.; PRIORI, A. Resistência democrática versus graves violações dos direitos...

ORDEM DOS ADVOGADOS DO BRASIL (OAB). O início da caminhada. Disponível em: https://www.oab.org.br/historiaoab/inicio.htm\#criacaoordem. Acesso em: 14 set. 2019.

PEREIRA, Anthony W. Ditadura e repressão: o autoritarismo e o Estado de Direito no Brasil, no Chile e na Argentina. São Paulo: Paz e Terra, 2010.

PRIORI, Angelo. Polícia política e ordenamento jurídico (Paraná: 1930-1964). In: MUNIZ, Altemar da Costa; MARTINS, Luis Carlos dos Passos (Orgs.). História política: interfaces e diálogos. Porto Alegre: Edipucrs; Fortaleza; Eduece, 2016, p. 205-230.

PRIORI, Angelo; KISCHENER, Manoel Adir. Conversas sobre direitos e dignidade humana. In: PRIORI, Angelo; FELIPE, Delton Aparecido; PEREIRA, Márcio José (Orgs.). Conversas sobre direitos humanos e práticas educativas no espaço escolar. Maringá: Edições Diálogos, 2019, p.9-24.

PROJETO Brasil: Nunca mais. <http://bnmdigital.mpf.mp.br/sumarios/600/551.html>. Acesso: 10 jul. 2019.

REZNIK, Luís. Democracia e segurança nacional: a polícia política no pós-guerra. Rio de Janeiro: Ed. FGV, 2004.

ROLLEMBERG, Denise. Memória, opinião e cultura política: a Ordem dos Advogados do Brasil sob a ditadura (1964-1974). In: AARÃO REIS, Daniel; ROLLAND, Denis (Orgs.). Modernidades Alternativas. Rio de Janeiro: FGV, 2008, p. 1-37. Disponível em: <http://www.historia.uff.br/nec/memoria-opiniao-ecultura-politica-ordem-dos-advogados-do-brasil-sob-ditadura-1964-1974>. Acesso em: 14 jul. 2019.

SILVA FILHO, José Carlos Moreira. Crimes do Estado e justiça de transição. In: GAUER, Ruth Maria Chittó (Org.). Criminologia e sistemas jurídico-penais contemporâneos. 2a . Ed. Porto Alegre: Edipucrs, 2012, p. 45-68.

SILVA, Ângela Moreira Domingues. Ditadura militar e justiça castrense no Brasil: espaço de legitimação política e de contradições (1964-1985). Disponível em: <http://www.arqanalagoa.ufscar.br/abed/Integra/Angela\%20Moreira\%2013-0807.pdf>. Acesso em: 10 jul. 2019.

SILVA, Márcia Pereira. História e culturas políticas: as concepções jurídicas evocadas pelos governos militares enquanto instrumento de obtenção de legitimidade. História. São Paulo, n. 28, v. 2, p. 17-42, 2009. 
SPIELER, Paula; QUEIROZ, Rafael Mafei Rabelo. Advocacia em tempos difíceis: ditadura militar 1964-1985. Curitiba: Edição do Autor, 2013.

TELLES, Janaína de Almeida. Em defesa da liberdade e da justiça: os advogados de perseguidos políticos de São Paulo nos anos 1970. Revista Brasileira de Ciências Criminais, v. 102, p. 287-308, 2013.

RECEBIDO EM: 10/08/2019

APROVADO EM: 09/09/2019 